\title{
Application of silase waste fruit leather technology in Suka village, Kecamatan Tigapanah, Karo District
}

\author{
Peni Patriani ${ }^{1 *}$, Nurzainah Ginting ${ }^{1}$, Uswatun Hasanah ${ }^{1}$, R. Edhy Mirwandhono ${ }^{1}$ \\ ${ }^{1}$ Department of Agricultural Technology, Faculty of Agriculture, Universitas Sumatera Utara \\ *Email: penipatriani@usu.ac.id
}

\begin{abstract}
Karo Regency is one of the biggest coffee producing regions in North Sumatra Province. Plantation waste byproduct from coffee production is the coffee seed waste which is usually discarded and causes environmental pollution. The purpose of this community service is to apply the waste of coffee fruit skin into sheep and goat feed using silage technology so that it can reduce the cost of feed for farmers. The method used is interviews and finding solutions to problems, training accompanied by practice using teaching media such as guidebooks, leaflets and banners, assistance and reinforcement supported by equipment from the service team so farmers are more interested. Outcomes of community service programs are improving farmers 'knowledge and skills, reducing the cost of animal feed using abundant coffee seed waste, reducing environmental pollution, developing the concept of business integration between plantations and animal husbandry so as to increase farmers' incomes. The results obtained are based on a long-term indicator that the utilization of coffee fruit seed waste using silage technology for animal feed can reduce feed costs, increase livestock production, increase farmers' skills and knowledge and can overcome waste pollution. It was concluded that silage technology using coffee seed waste is very effective to improve science, environmental health, income and farmers' standard of living.
\end{abstract}

Keyword: Waste, coffee fseed waste, silage, technological applications

\begin{abstract}
Abstrak
Kabupaten Karo adalah salah satu daerah penghasil kopi terbesar di Provinsi Sumatera Utara. Produk samping limbah perkebunan dari produksi kopi adalah limbah biji kopi yang biasanya dibuang dan menyebabkan pencemaran lingkungan. Tujuan dari layanan masyarakat ini adalah untuk menerapkan limbah kulit buah kopi ke dalam pakan domba dan kambing menggunakan teknologi silase sehingga dapat mengurangi biaya pakan bagi petani. Metode yang digunakan adalah wawancara dan menemukan solusi untuk masalah, pelatihan disertai dengan praktik menggunakan media pengajaran seperti buku panduan, selebaran dan spanduk, bantuan dan penguatan yang didukung oleh peralatan dari tim layanan sehingga petani lebih tertarik. Hasil dari program layanan masyarakat adalah meningkatkan pengetahuan dan keterampilan petani, mengurangi biaya pakan ternak menggunakan limbah biji kopi yang berlimpah, mengurangi polusi lingkungan, mengembangkan konsep integrasi bisnis antara perkebunan dan peternakan sehingga dapat meningkatkan pendapatan petani. Hasil yang diperoleh didasarkan pada indikator jangka panjang bahwa pemanfaatan limbah biji kopi menggunakan teknologi silase untuk pakan ternak dapat mengurangi biaya pakan, meningkatkan produksi ternak, meningkatkan keterampilan dan pengetahuan petani dan dapat mengatasi polusi limbah. Disimpulkan bahwa teknologi silase menggunakan limbah biji kopi sangat efektif untuk meningkatkan ilmu pengetahuan, kesehatan lingkungan, pendapatan dan standar hidup petani.
\end{abstract}

Kata Kunci : Limbah, limbah biji kopi, silase, aplikasi teknologi

\section{PENDAHULUAN}

Kabupaten Karo merupakan wilayah dataran tinggi yang terletak di Provinsi Sumatera Utara dengan luas wilayah 2.127,25 Km2 atau 212.725 Ha (Badan Pusat Statistik, 2017). Kabupaten karo sebagian besar masyarakat bermata pencaharian sebagai petani dan peternak. Hasil pertanian dan perkebunan berkembang pesat karena topografi lingkunganya sangat baik. Kabupaten karo merupakan salah satu kabupaten yang menghasilkan kopi terbesar di Sumatera Utara dengan luas tanaman 5.010 ha dari 
total 7.741 ha. Produksi kopi di Mitra dalam pengabdian yang dilakukan adalah Gapoktan atau Gabungan kelompok tani "Merih" yang membawahi forum petani dan peternak di Desa Suka, Kecamatan Tigapanah Kabupaten Karo. Peternak di Desa Suka, masih memelihara ternaknya secara tradisional dengan membeli pakan konsentrat dan hijauan atau limbah pertanian.

Permasalahan yang timbul jika musim kemarau tiba dimana hijauan berkurang maka peternak menghadapi kesulitan mendapatkan pakan ternak. Kabupaten Karo di tahun 2016 meningkat menjadi 7485,85 ton yang dinaungi oleh 19 perusahaan yang menangani produksi kopi sekaligus pengupasan kulitnya. (Badan Pusat Statistik, 2017). Pemanfaatan limbah kulit buah kopi sendiri belum dilakukan secara maksimal. Selain hal tersebut pencemaran limbah dari limbah kulit kopi menyebabkan pencemaran bau yang tidak sedap dan meningkatkan jumlah lalat sehingga menggangu kesehatan ternak maupun manusia.

Mengingat populasi kambing di Kabupaten karo yang cukup pesat, tercatat pada tahun 2016 jumlah populasi kambing 12.591 ekor. (Badan Pusat Statistik, 2016). Untuk mengatasi kedua permasalahan tersebut diperlukan suatu sentuhan teknologi yang mudah diadopsi, mudah dan murah sehingga membawa manfaat.

Aplikasi teknologi silase menggunakan limbah kulit kopi adalah salah satu alternatif yang cukup tepat. Sebenarnya kulit kopi segar dapat digunakan sebagai pkan ternak tetapi akan berdampak pada pencernaan ternak kambing seperti mencret dan palabilitas yang kurang disukai ternak karena kandungan lignin, serat kasar, cafein dan tannin yang tinggi.

Efendi dan Harta (2013) menyatakan bahwa silase dapat mengurangi kandungan serat kasar dan tannin sehingga dapat meningkatkan palabilitas, daya cerna dan kandungan protein dalam bahan pakan. Prawirodigdo et.al (2005) menyatakan mengaplikasikan silase limbah kulit kopi 200 gram per hari aman selain dapat mengatasi kesulitan pakan pada musim kemarau.

Silase limbah kulit buah kopi juga telah diteliti oleh Simanihuruk dan Sirait (2010) yang memberikan silase kulit kopi $20 \%$ dari total ransum yang digunakanya sebagai pengganti rumput. Pemberian limbah kulit kopi amoniasi pada ternak unggas juga merupakan pakan alternatif terhadap pertambahan bobot badan (Khalil, 2016).

Zainuddin dan Murtisari (1995) menyatakan bahwa limbah kuli buah kopi sangat potensial jika dimanfaatkan sebagai pakan ternak. Diperkuat oleh Guntoro et al (2002) bahwa penggunaan kulit kopi fermentasi sebagai pakan ternak mampu nuntuk meningkatkan pertambahan bobot badan ternak dari rataan $68.41 \mathrm{~g} / \mathrm{ekor} / \mathrm{hari}$ menjadi $102.92 \mathrm{~g} / \mathrm{ekor} / \mathrm{hari}$.

Kegiatan yang dilakukan oleh tim abdimas USU adalah memberi transver ilmu pengetahuna dan keterampilan peternak dalam pembuatan silase kulit buah kopi, meyusun ransum yang tepat dalam pengaplikasianya dari hasil praktik yang dilakukan peserta yakni kelompok tani.

Pendampingan dan penguatan dimaksutkan untuk memotivasi agar peternak yang kurang paham menjadi lebih tau, mampu dan mau secara sadar dan mandiri mengaplikasikan teknologi ini sehingga permasalahan yang ada dapat terselesaikan.

\section{METODE PELAKSANAAN}

Gapoktan merih sebagai mitra yang sbagian besar anggotanya adalah petani dan peternak berjumlah 25 orang. Tim pengabdian sebelumnya telah melakukan observasi dan wawancara menggunakan quisioner, pengenalan program pengabdian yang akan dilakukan, melakukan pelatihan, praktik, pendampingan dan penguatan. Jenis kegiatan yang dilaksanakan oleh tim pengabdian adalah survai awal, wawancara tentang permasalahan yang dihadapi petani dan peternak, sosialisasi kegiatan, pelatihan dan praktik, aplikasi teknologi disertai pendampingan dan pemantauan serta pemantapan dan penguatan kegiatan.. Sedangkan tanggungjawab mitra atau kelompok tani Merih yakni berpartisipasi pada seluruh rangkaian kegiatan, membantu bahan dan prasarana kegiatan, mempraktikan dan mengaplikasikan pembuatan silase yang telah dipelajari dalam kegiatan pelatihan. 


\section{HASIL DAN PEMBAHASAN}

Pengabdian masyarakat merupakan transver ilmu pengetahuan dan keterampilan kepada masyarakat yang dapat diadopsi oleh petani dan peternak yang bersangkutan.

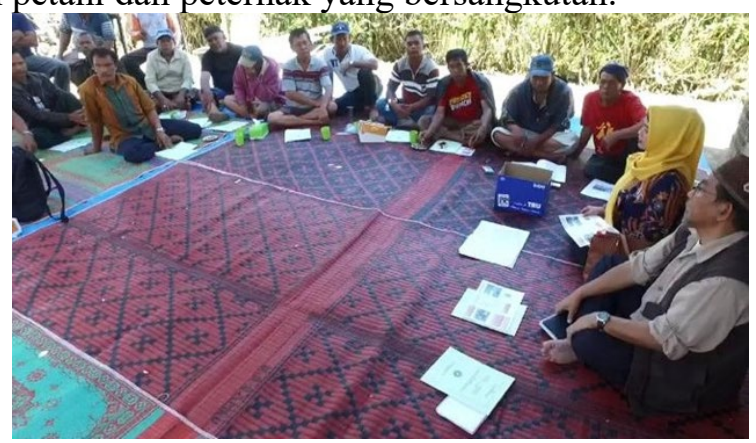

Gambar 3.1. Pelatihan Pembuatan Silase

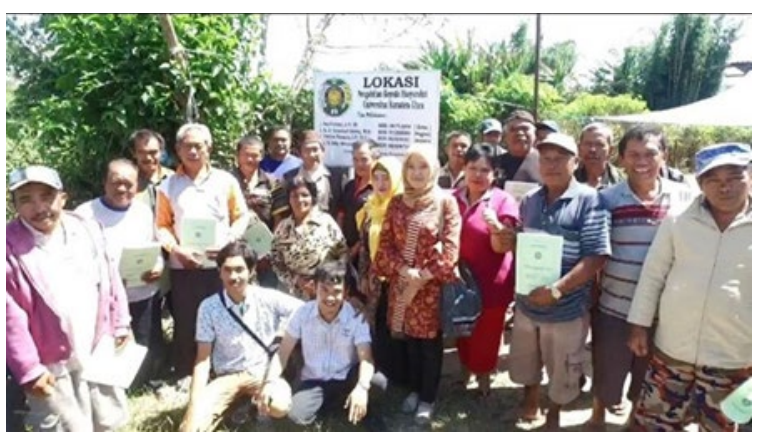

Gambar 3.2. Peserta Pelatihan Pembuatan Silase

Pada pelatihan proses adopsi inovasi berjalan dengan lancer, petani dan peternak sangat antusias. Hal tersebut, dapat terlihat pada petani dan peternak saat sesi Tanya jawab dengan tim abdimas. Perubahan pola pikir petani dapat diketahui dengan perubahan pandangan bahwa pemanfaatan limbah kulit kopi yang melimpah dengan teknologi silase dapat mengurangi biaya pakan dan pencemaran lingkungan selain praktis untuk dilakukan.

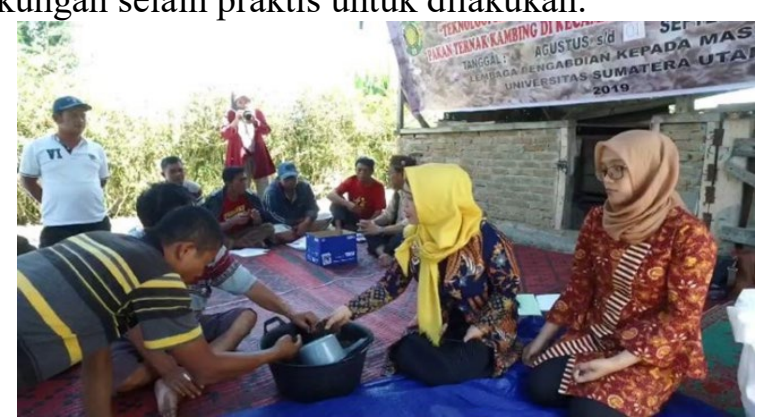

Gambar 3.3. Praktik pembuatan silase

Pelatihan dan praktik yang dilakukan dengan menggunakan leaflet, banner dan buku panduan membuat petani dan peternak lebih tertarik dan memotivasi untuk jiwa wirausaha pada peternakan yang masih tradisional menjadi lebih modern dengan memperhitungkan biaya pakan, menyusun ransum dan memanfaatkan sumber daya alam yang melimpah.

Setelah melaksalakan kegiatan pelatihan dan praktik, tim abdimas memberikan masukan untuk kelompok tani mempraktikan teknologi silase dalam pembuatanya yang nantinya akan dilaksanakan pendampingan lebih lanjut untuk mengetahui keberhasilan peternak dalam ppembuatan silase. Waktu yang dibutuhkan sekitar 2 minggu untuk tim pengabdian kembalki memberi arahan, bimbingan dan pendampingan jika kualitas silase masih dirasa kurang baik. 
Indikator capaian berdasarkan kuisioner yang telah dilaksanakan dalam kegiatan pengabdian ini meliputi:

\subsection{Aplikasi teknologi silase yang telah dilaksanakan Peternak dan Gapoktan Merih pada indikator jangka panjang}

Monitoring dan evaluasi yang telah dilakukan oleh tim pengabdian masyarakat di Desa Suka Kecamatan Tigapanag Kabupaten Karo didapatkan hasil bahwa para peternak dan kelompok tani telah mempraktikan teknologi silase. Para peternak menggunakan peralatan yang telah diberikan oleh tim pengabidian dengan baik. Masing-masing peternak mencoba mempraktekan membuat silase per orang 15 kilo limbah dengan masa pemeraman 15 hari.

Pada acara monitoring dan evaluasi, silase yang dibuat masih dalam proses pemeraman sekitar 1 minggu dilakukan 5 orang peternak, sedangkan yang telah berhasil membuat silase limbah kulit buah kopi yaitu 12 orang dengan kualitas silase baik 12 orang dan cukup baik 1 orang.

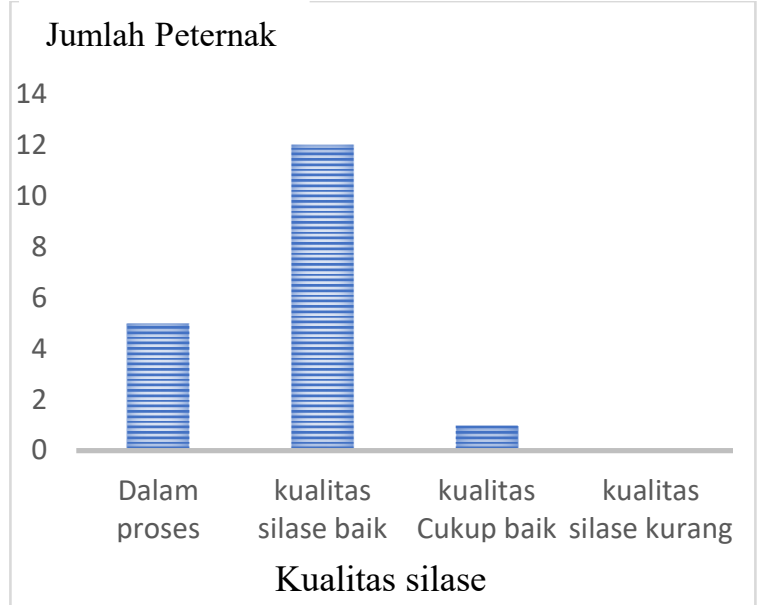

Gambar 3.4. Grafik Aplikasi Teknologi Silase Kelompok Tani Merih di Desa Suka, Tigapanah, Kabupaten Karo

Hal ini berarti teori adopsi inovasi dalam kegiatan pelatihan telah mencapai progres yang cukup baik. Pada form isian data quisioner jumlah total yang peternak yang mempraktekan teknologi silase menggunakan limbah kulit kopi sekitar 18 orang dari 20 peternak.

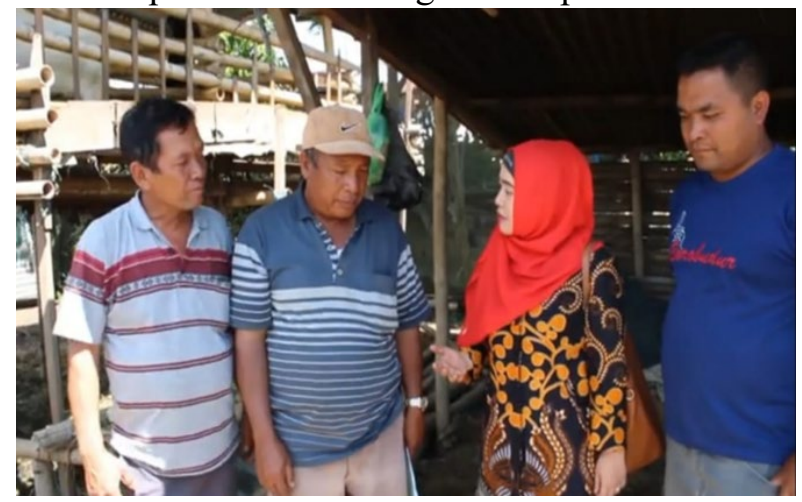

Gambar 3.5. Monitoring dan evaluasi

Peternak yang belum mempraktikan sebanyak 2 orang dikarenakan masih ragu dan takut silase yang dihasilkan akan mengalami kegagalan. Penyelesaian masalah untuk membuat peternak yakin, tim abdimas selanjutnya akan melaksanakan pendampingan dan bimbingan lebih lanjut 


\subsection{Progress kegiatan setelah pembinaan dan pendampingan kegiatan pengabdian masyarakat}

Pendampingan dan bimbingan lebih lanjut dilakukan oleh tim pengabdian untuk memantau sejauh mana silase yang dihasilkan berpengaruh terhadap produksi dan pertumbuhan ternak kambing yang diberi pakan menggunakan silase kulit buah kopi. Ternyata dari 20 peternak yang mengikuti pelatihan ada penambahan jumlah petani yang mengadopsi dan mempraktikan kulit buah kopi sebagai pakan ternak yakni sekitar 5 orang peternak yang sebagian besar merupakan kerabat dari para peternak yang mengikuti pelatihan. Mereka sangat tertarik karena melihat peternak yang mengikuti kegiatan pelatihan dapat menekan biaya pakan menggunakan limbah yang melimpah dilingkungan mereka. Pada kegiatan pendampingan ini para peternak mulai yakin bahwa teknologi silase yang diaplikasikan membawa dampak positif dan akan terus dilakukan pengaplikasianya pada formulasi pakan yang mereka susun.

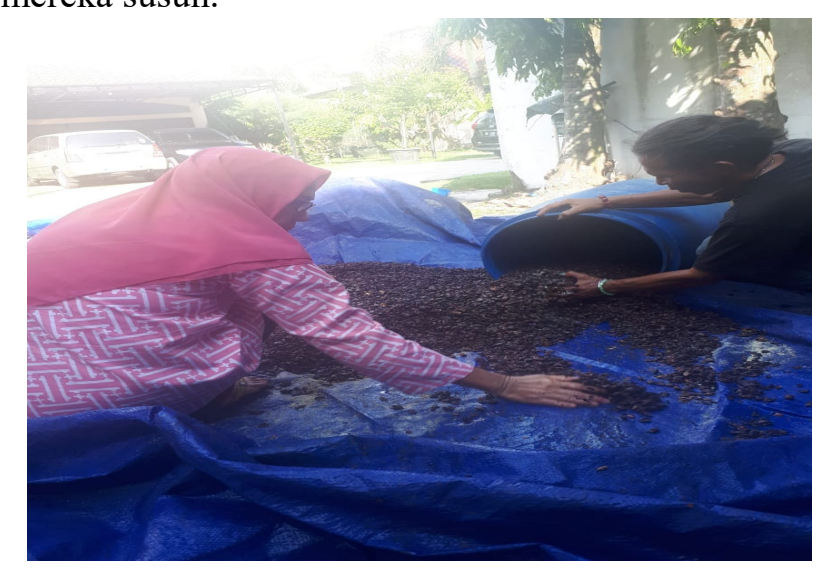

Gambar 3.6. Hasil Silase Limbah Kulit Buah Kopi Yang Di Praktikan Peternak Berkualitas Sangat Baik

Pada saat diskusi peternak menyampaikan bahwa pemberian silase $30 \%$ silase yang berkualitas dapat meningkatkan bobot badan kambing yang mereka peliharaan 0,96 kg selama 15 hari pengaplikasian. Mereka merasakan manfaat bahwa teknologi silase dapat mengurangi biaya pakan sehingga keuntungan yang didapat juga lebih tinggi.

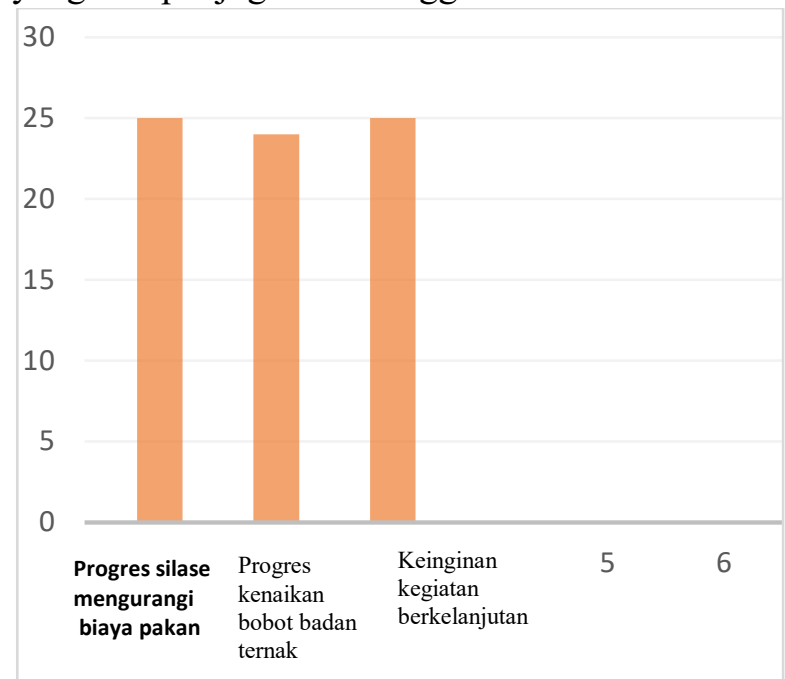

Gambar 3.7. Grafik Progress Kegiatan Setelah Pembinaan Dan Pendampingan Pengabdian Masyarakat 
Dapat dilihat bahwa peserta pendampingan sebanyak 25 orang telah menyampaikan hasil dari pengaplikasian teknologi silase kulit kopi sebagai pakan ternak yang telah mereka lakukan. Progres atau capaian kegiatan yang telah dilakukan didapatkan hasil bahwa 25 orang peternak merasakan pengaplikasian silase limbah kulit buah kopi mengurangi biaya pakan sekitar $40 \%$ dari yang biasa mereka keluarkan selama masa pemeliharaan hal ini berarti telah mencapai progres $100 \%$ tingkat adopsi yang dilakukan peternak. Capaian kenaikan bobot badan ternak seagai indikator keberhasilan peningkatan ilmu pengetahuan peternak dalam penyusunan pakan yang diformulasikan dengan silase, pada kegiatan 24 orang menyampaikan bahwa ternak kambing yang dipelihara mengalami kenaikan bobot badan sedangkan 1 orang masih dalam proses pengaplikasian dan belum sempai mnimbang bobot badan kambing. Keinginan untuk mengadopsi praktik penyuluhan dan motivasi pada pendampingan mendorong petani ingin kegiatan yang berkelanjutan sebanyak 25 orang. Hal ini berarti tim pengabdian berhasil mencapai progres transver teknologi, keterampilan dan ilmu pengetahuan sehingga peternak tau, mau, dan mampu bahwa aplikasi silase dapat membawa dampak kebaikan lingkungan muapun meningkatkan pendapatan.

\subsection{Penguatan dan pemantapan hasil kegiatan pengabdian masyarakat}

Pertemuan pemantapan dan penguatan kegiatan pengabdian kepada masyarakat pada kelompok tani merih beserta peternak dilakukan dengan maksud agar kegiatan aplikasi silase berkelanjutan dan lebih mandiri. Hal ini dimaksud agar aplikasi teknologi silase tetap dilaksanakan meski tanpa pendampingan secara intens lagi dari tim pengabdian.

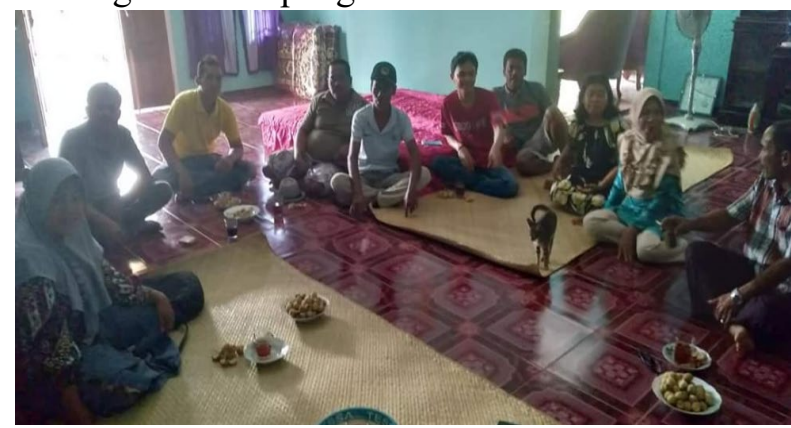

Gambar 3.8. Pemantapan dan Penguatan Kegiatan Pengabdian Masyarakat

Pada kegiatan pemantapan peternak dan gapoktan merih telah sepakat bahwa kegiatan aplikasi teknologi pembuatan silase tetap dilakukan hal ini karena manfaat yang mereka rasakan dari kegiatan tersebut membawa dampak perubahan cukup besar yakni pengurangi biaya pakan, peningkatan pendapatan dan mengupangi pencemaran lingkungan. Pada quisioner yang diisi bahwa para peternak puas terhadap pengabdian yang dilakukan oleh tim pengabdian.

Pengabdian kepada masyarakat yang telah dilakukan membawa perubahan pola pikir petani dan peternak Merih di Desa Suka, Tigapanah kabupaten Karo. Petani dan peternak berkeingina melaksanakan kegiatan ini secara mandiri 


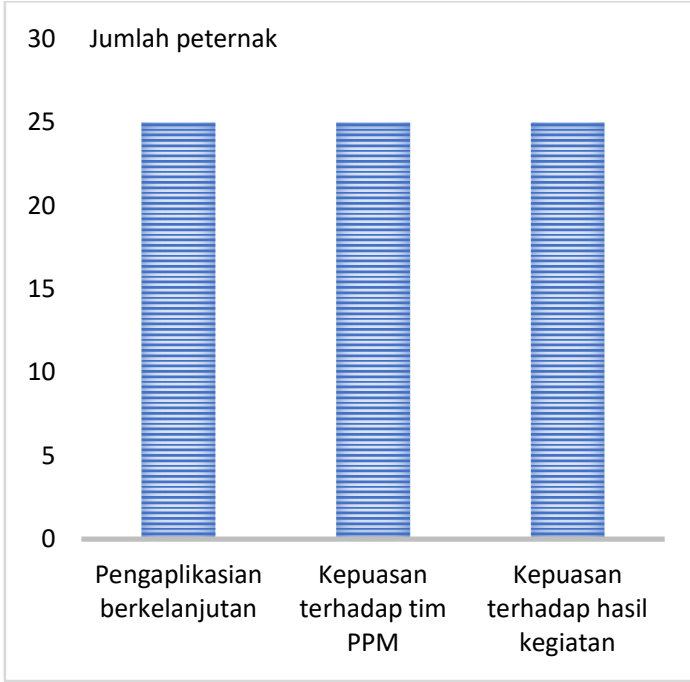

Gambar 3.9. Grafik Kepuasan Peternak Pada Kegiatan Pengabdian Masyarakat

Didapat hasil bahwa semua peserta pengabdian masyarakat akan melaksanakan atau mengaplikasikan teknologi silase secara berkelanjutan. Tingkat kepuasan peternak dan kelompok tani pada pelaksaan tim pengabdian dan hasil yang didapat 25 orang merasakan merasakan puas dan hasil yang didapat juga bermanfaat dalam meningkatkan usaha bidang peternakan yang mereka kelola. Hal ini berarti progres atau capaian kegiatan pengabdian tercapai $100 \%$.

\section{KESIMPULAN}

Pengabdian kepada masyarakat yang telah dilaksanakan selama 6 bulan dapat membawa dampak positif pada peternak. Teknologi silase limbah kulit buah kopi yang telah diaplikasikan memberi dampak berkurangnya pencemaran lingkungan karena limbah perkebunan, efisiensi pakan ternak domba dan kambing serta peningkatan produksi yang dapat dilihat dari pertambahan bobot badan ternak. Hal ini tampak pada wawancara dan kuisioner, petani telah mengadopsi dan mempraktekan teknologi silase pada limbah kulit buah kopi secara sukarela, yang tadinya tidak termanfaatkan dan sebagai sumber pencemaran menjadi produk yang termanfaatkan dan memberi keuntungan.

\section{UCAPAN TERIMAKASIH}

Artikel pengabdian kepada masyarakat ini merupakan hasil pengabdian mono tahun dosen muda yang dibiayai oleh NON PNPB Universitas Sumatera Utara Sesuai dengan Surat Perjanjian Penugasan Pelaksanaan Pengabdian kepada Masyarakat Program Program Mono Tahun Dosen Muda Tahun. Anggaran 2019, Nomor : 331/UN5.2.3.2.1/PPM/2019, Tanggal 20 Mei 2019. Oleh karena itu Kami Tim Pengabdian kepada Masyarakat mengucapkan terimakasih pada Rektor Universitas Sumatera Utara atas dukunga dana dan fasilitas dalam kegiatan ini. Kami juga berterimakasih pada Lembaga Pengabdian Universitas Sumatera Utara dan Mitra pada kegiatan Pengabdian Kepada Masyarakat ini.

\section{DAFTAR PUSTAKA}

Badan Pusat Statistik. 2017. Kabupaten Karo Dalam Angka BPS. Provinsi Sumatera Utara

Badan Pusat Statistik. 2016. Kabupaten Karo Dalam Angka, BPS. Provinsi Sumatera Utara 
Guntoro, S. \& I.M.R. Yasa. (2005). Pengaruh penggunaan limbah kopi terfermentasi terhadap produktivitas susu kambing. Prosiding Seminar Nasional Pemasyarakatan Inovasi Teknologi Revitalisasi Pertanian dan Pedesaan di Lahan Marginal, Hal: 562-565

Khalil, M. (2016). Pengaruh pemberian limbah kulit kopi (Coffea sp) amoniasi sebagai pakan alternatif terhadap pertambahan bobot ayam broiler. Jurnal Ilmiah Mahasiswa Pendidikan Biologi, Vol 1, Issue 1.

Prawirodigdo, S. T. Herawati dan B. Utomo. (2005). Pemanfaatan kulit kopi sebagai komponen pakan seimbang untuk penggemukan ternak domba. Prosiding Seminar Nasional Teknologi Peternakan dan Veteriner Hal 438-444.

Simanihuruk K, J Sirait. (2010). Silase Kulit Buah Kopi Sebagai pakan pada kambing boerka. Seminar Nasional Teknologi Peternakan

Z Efendi dan L Harta. 2013. Kandungan nutrisi hasil fermentasi kulit kopi (Studi kasus desa air meles bawah kecamatan curup timur). BPTP Bengkulu. bengkulu.litbang.pertanian.go.id

Zainuddin, D. \& T. Murtisari. (1995). Penggunaan limbah agro-industri buah kopi (kulit buah kopi) dalam ransum ayam pedaging (Broiler). Pros. Pertemuan IImiah Komunikasi dan Penyaluran Hasil Penelitian. Semarang. Sub Balai Penelitian Klepu, Puslitbang Petemakan, Badan Litbang Pertanian, Hal : 71-78. 